\title{
THE EFFECT OF REGIONAL ORIGINAL INCOME (PAD), GENERAL ALLOCATION FUNDS (DAU), SPECIAL ALLOCATION FUNDS (DAK) AND AREA OF AREAS ON CAPITAL EXPENDITURE (Case Study in Regency / City on Java Island in 2016)
}

\author{
Marsyaf Lawe Anasta
}

\begin{abstract}
This research aims to know the influence of Regional Original Revenue, General Allocation Fund, Special Allocation Fund and Area Size on Capital Expenditures. The object for this research is the city and regency government in Java. The sample used a census method or population method that takes all the data as a sample. This study uses secondary data in the form of Budget Realization Report on Regional Budget (APBD) in 2016. Data analysis method used is statistical analysis in the form of multiple linear regression test. The results of this research indicate that simultaneously the variables of Regional Original Revenue, General Allocation Fund, Special Allocation Fund and Area Size have a significant effect on Capital Expenditures. Partially, the variables of Regional Original Revenue, Special Allocation Fund and Area Size have a significant effect on Capital Expenditures. While the General Allocation Fund variable did not significantly influence on Capital Expenditures. Keywords: regional original revenue, general allocation funds, special allocation funds, area, capital expenditure, PAD, DAU, DAK.
\end{abstract}

DOI: $10.7176 / \mathrm{EJBM} / 11-16-14$

Publication date:June $30^{\text {th }} 2019$

\section{Introduction}

With the enactment of policies from the government regarding regional autonomy, there have been many changes in the Indonesian government system. Policies related to regional autonomy were initially regulated in Law No. 22 of 1999 concerning Regional Government which was later replaced by Law No. 32 of 2004, Law Number 12 of 2008, Law Number 23 of 2014 concerning Regional Government, then changes were made to several articles and the publication of Law No. 2 of 2014 concerning Amendments to Law No. 23 of 2014 and Law No. 9 of 2015 concerning the Second Amendment to Law No. 23 of 2014.

In contrast to the centralized government system which is a fiscal burden for the APBN, the decentralization system emphasizes the use of the role of the APBD. Law Number 33 of 2004 concerning Financial Balance between the Central Government and Regional Governments, defines the APBD as the annual financial plan of the regional government which is discussed and approved by the regional government and the Regional People's Representative Council (DPRD) then stipulated by Regional Regulation (Perda). Law No. 17 of 2003 states that APBD is the basis for regional financial management which is a guideline for LGs in providing services to the public within a budget year. APBD consists of regional income budget, regional budget, and regional financing. The function of the APBD is the functions of authorization, planning, supervision, allocation, distribution and stabilization.

Changes in the Government's system brought changes to the government system from centralization to decentralization between the central government and regional governments increasingly reinforced by the enactment of Law No. 33 of 2004 concerning Financial Balance between the Central Government and Regional Governments. Changes in the Government's system brought changes to the government system from centralization to decentralization between the central government and regional governments strengthened by the enactment of Law No. 33 of 2004 concerning Financial Balance between the Central Government and Regional Governments. Provision of Balancing Funds aims to reduce fiscal inequalities between the central government and local governments as well as between regional governments related to the differences in potential possessed by each region.

The Balancing Fund consists of Revenue Sharing Funds (DBH), General Allocation Funds (DAU), and Special Allocation Funds (DAK). In addition to the balance funds, the regional government also has a source of revenue called Regional Original Income (PAD). Regional Original Income is a component of revenue sources derived from local taxes, regional retributions, separated regional wealth management results, and other legitimate PAD. 
In addition, in Law Number 33 of 2004 concerning Financial Balance between the Central Government and Regional Governments, several variables are mentioned which reflect the need for the provision of public facilities in each region. One of these variables is the area. Regions that have large areas require a better number of facilities as a condition for service to the community compared to areas with smaller areas.

Local governments have the authority to determine the allocation of resources owned for regional expenditures and make regional policies to provide improvements to the service sector, increase participation, initiatives and community empowerment aimed at improving people's health. The Regional Government is required to optimize the potential income that is owned both from the original regional income sources and from the sources of government balance funds, one of which is by giving a larger portion of regional expenditure to sectors that affect the productivity of the local community. Increased capital investment in the form of fixed assets, namely investment in land assets, buildings, infrastructure, equipment and other fixed assets is a regional expenditure that can increase the productivity level of a region. Regional expenditure for productive sectors in terms of investment is called capital expenditure.

Government Regulation Number 71 of 2010 concerning Government Accounting Standards, defines capital expenditure as the allocation of budget expenditures used for the acquisition of fixed assets and other assets that can benefit more than one accounting period. A larger proportion of the allocation of capital expenditure will be directly proportional to the increase in facilities and infrastructures in an area. An area that has good facilities and infrastructure can automatically increase the productivity and quality of its area. In an effort to improve regional quality, the government should optimize the management of regional budgets, one of which is to provide more capital expenditure allocation of capital expenditure.

This study broadly aims to identify the influence of PAD, DAU, DAK and Area on Capital Expenditures in the 2016 fiscal year in all cities and districts in Java. The research object chosen was the city and regency government in Java Island which was found in the 2016 Regional Budget Realization. There were two differences between this study and previous research. The first difference is that this study uses a sample of municipal and regency governments on the island of Java in the 2016 financial year. The second difference is that the independent variables used are PAD, DAU, DAK and the Area on Java.

\section{LITERATURE REVIEW}

Government Regulation No. 71 of 2010 concerning Government Accounting Standards defines Capital Expenditures is budget expenditures for the acquisition of fixed assets and other assets that provide benefits more than one accounting period. Capital expenditures include capital expenditures for land acquisition, buildings and buildings, equipment, and assets intangible. Minister of Finance Regulation No. 127 / PMK.02 / 2015 concerning Classification The capital expenditure budget is categorized into 5 (five) main categories namely Land Capital Expenditures, Equipment and Machine Capital Expenditures, Building and Building Capital Expenditures, Road Capital Expenditures, Irrigation and Networks, and Other Capital Expenditures.

Local revenue (PAD) is a source of income for local governments that are collected based on local regulations that are useful for building regional infrastructure. PAD consists of regional taxes, regional levies, the results of separated regional wealth management, and other legitimate local revenues. According to Halim (2004) Regional Original Income is all regional revenues originating from regional economic sources. As stated that Regional Original Income is regional revenue originating from regional economic sources, it is expected that each local government can develop economic infrastructure in their respective regions in order to increase their income. (Mardiasmo, 2002).

Law No. 33 of 2004 concerning Balancing Funds defines DAU as funds sourced from the State Revenue and Expenditure Budget (APBN) which are allocated with the aim of equitable distribution of financial capacity between regions to fund regional needs in the context of implementing fiscal decentralization. DAU is one of the main sources of income for provincial, district and municipal governments that have a large proportion of the APBD budget. DAU for a region is determined based on certain criteria which emphasize the aspect of equity and justice which is in line with the administration of government affairs and the calculation of the DAU is determined according to the law (Sudaryo, Sjarif and Sofiati, 2017). Based on Minister of Home Affairs Regulation No. 26 of 2006 concerning APBD Preparation Guidelines, that the use of DAU to prioritize its use to fund salaries - benefits, employee welfare, operation - maintenance activities, and physical construction of facilities and infrastructure in order to improve basic services, and public services needed by the community. 
Special Allocation Funds (DAK) are one of the balancing funds originating from the APBN allocated to regional governments with the aim of helping to fund special activities which are regional affairs and in accordance with national priorities. The amount of DAK for regions is determined by the government every year in the APBN. The use of DAK is directed at development investment activities, procurement, upgrading, repair of physical facilities and infrastructure for public services with a long economic life, including the procurement of supporting physical facilities, and not including capital participation. (Sudaryo, Sjarif and Sofiati, 2017)

According to Law No. 26 of 2007 concerning spatial planning, territory is a space which is a geographical unit along with all elements related to it whose boundaries and systems are determined based on administrative aspects and / or functional aspects. Whereas Law No. 23 of 2014 concerning regional government defines regional coverage is the district / city area which will become the coverage area of the province or sub-district which will become the coverage of the regency / city area.

\section{HYPOTHESIS}

\section{Regional Original Income (PAD)}

Fiscal decentralization gives authority to regional heads to manage and regulate all government affairs by creating regional policies to provide services, increase participation, initiatives and empowerment of local communities aimed at improving community welfare. The ability of the regions to provide sources of income originating from the regions is highly dependent on the ability to realize the economic potential of the local area into a form of economic activity that is able to create regional revenues to finance the development of the area. The size of capital expenditure will be determined from the size of the PAD received. So that, if local governments want to improve public services and public welfare by increasing capital expenditures, the local government must strive to explore PAD as much as possible (Nuarisa, 2013). So with higher PAD, this can affect the size of the regional capital expenditure budget to improve services to the public. Services to the public will be better and the infrastructure built will be more evenly distributed.

H1: Regional Original Income (PAD) affects the allocation of capital expenditure.

\section{General Allocation Fund (DAU)}

The allocation of DAU from the influential central government is very dominant. It is undeniable that DAU is a form of financing for regional government activities that supports a large portion of revenue in the APBD. Of course, the amount of DAU allocation has a very significant effect on regional government expenditures, both routine and investment.

In several studies that have been done, it is known that DAU has a positive influence on the allocation of capital expenditure. One of them is the research conducted by Darwanto and Yustikasari (2007) which explains the effect of economic growth, PAD, and DAU on the allocation of capital expenditure budgets. The study concluded that economic growth (GRDP) had a positive but not significant effect, while PAD and DAU had a positive and significant relationship with capital expenditure. This research is reinforced by other studies conducted by Tuasikal (2008), Yovita (2011), Nuarisa (2013) and Menes (2013) who also concluded that DAU had a positive and significant effect on the allocation of capital expenditure.

In a data it is stated that $70.3 \%$ of regional government expenditure or IDR 196.87 trillion is allocated through DAU (Menes, 2013). DAU as the government's main source of income is very likely to play an important role in determining the amount of capital expenditure allocation in the APBD, so that the hypothesis obtained is as follows.

H2: General Allocation Fund (DAU) affects the allocation of capital expenditure.

\section{Special Allocation Funds (DAK)}

Special Allocation Fund (DAK) is one of the balancing funds originating from the APBN allocated to certain regions with the aim of helping to fund special activities which are regional affairs and according to national priorities. DAK as one of the balancing funds is a fund intended to be directed at development investment activities, procurement, improvement, and repair of physical facilities and infrastructure with a long economic life, including the procurement of supporting physical facilities and not including capital participation. The existence of DAK 
allocations is expected to affect capital expenditure, because DAK tends to add fixed assets owned by the government to improve public services (Nuarisa, 2013).

In the research conducted by Novianto and Hanafiah (2015), it was shown that partially the DAK had a positive and significant influence on the allocation of capital expenditure. This is inversely proportional to the results of research from the research conducted by Darmayasa and Suandi (2014) with the results of DBH and DAU having a positive and significant effect on Capital Expenditures (DBH and DAU are determinants of Capital Expenditure allocation), but PAD, DAK, and Employee Expenditures have no effect significant to capital expenditure.

The large contribution of DAK in the balancing funds of a local government and at the same time shows the government's efforts in efforts to build infrastructure in both cities and districts in Indonesia. The amount of the DAK will be directly proportional to the amount of capital expenditure of the regional government. Based on the explanation, the following hypothesis is formulated.

H3: General Allocation Funds (DAK) affect the allocation of capital expenditure.

\section{Area Size}

The government capital expenditure budget is based on regional needs for facilities and infrastructure, both for the smooth implementation of government duties and for public facilities. In the explanation of Law No. 33 of 2004 concerning Balancing Funds, one of the variables that reflects the need for the provision of facilities and infrastructure is the area. Regions with a wider area certainly need more facilities and infrastructure as a condition for service to the public when compared to areas with areas that are not so wide. (Kusnandar and Siswantoro, 2012)

In his research on the effect of general allocation funds, local revenues, the remaining budget financing and the area to capital expenditure, Kusnandar and Siswantoro (2012) concluded that partially the area affected capital expenditure. So that if the area of the area tends to be wider compared to other regions, this affects the amount of capital expenditure allocated to public services.

Public service media that are good in a wider range of regional areas indicate the operational success of regional government because it can affect community service activities in accordance with previously set targets. With the fulfillment of targets by the government in public services, the capital expenditure budget is also fulfilled, which is one form of public service that will be felt by the community. With differences in each area of regional government, it will affect the amount of capital expenditure allocation. Then the hypothesis is arranged as follows.

H4: Area size affects the allocation of capital expenditure

\section{METHOD}

This research focuses on the local government and the island city of Java in Indonesia. This study aims to test the hypothesis (hypothesis testing) with independent variables (independent variables) and Bound Variables (dependent variables). The independent variable consists of Regional Original Income (PAD), General Allocation Fund (DAU), Special Allocation Fund (DAK) and Area. The dependent variable used is Capital Expenditures. The data that will be used in this study are secondary data in the form of the 2016 Regional Revenue and Expenditure Budget (APBD) Report and area wide data on the regency and municipal governments in Java, which amount to 119 districts / cities in 2016. This research is research using census or population methods, thus making all data as samples. The study carried out was cross section because the population used was only one year. There are 119 sample data in this study, of which only 119 data can be used as research samples. This is because 13 sample data are Outlier data.

This study uses an analytical method that is descriptive analysis method with SPSS Version 23 software to help data analysis process. The statistical analysis used for testing the hypothesis in this study is multiple linear regression analysis by first carrying out the classical assumption test. The classic assumption test that is carried out is the data normality test, multicollinearity test and heteroscedasticity test. Hypothesis testing is done by testing the coefficient of determination (R2), F (simultaneous) statistical test and $\mathrm{t}$ (partial) statistical test. 


\section{RESULTS AND DISCUSSION}

A. Descriptive Statistics Test Results

\begin{tabular}{|c|c|c|c|c|c|}
\hline & $\mathrm{N}$ & Minimum & Maximum & Mean & $\begin{array}{c}\text { Std. } \\
\text { Deviation }\end{array}$ \\
\hline BM & 106 & 146.99 & 1789.39 & 498.9313 & 309.29727 \\
\hline PAD & 106 & 66.39 & 4091.87 & 462.3203 & 545.00725 \\
\hline DAU & 106 & 397.09 & 11621.02 & 1104.9353 & 1082.29799 \\
\hline DAK & 106 & 83.33 & 645.09 & 274.3531 & 119.21244 \\
\hline LW & 106 & 16.06 & 5782.40 & 1164.2703 & 1001.83867 \\
\hline $\begin{array}{l}\text { Valid N } \\
\text { (listwise) }\end{array}$ & 106 & & & & \\
\hline \multicolumn{6}{|c|}{$\begin{array}{l}\text { Keterangan; } B M=\text { Belanja Modal; PAD= Pendapatan Asli Daerah; } \\
\text { DAU=Dana Alokasi Umum; DAK= Dana Alokasi Khusus; } L W= \\
\text { Luas Wilayah; }\end{array}$} \\
\hline
\end{tabular}

Descriptive statistics serve to describe a data through the mean (mean), standard deviation, variance, maximum, minimum, sum, range, kurtosis, and skewness (inclination of distribution) (Ghozali, 2016). This study only uses statistical test data in the form of minimum, maximum, mean (average), and standard deviation using SPSS 23. The minimum is used to find the lowest value of the variables in the study. The maximum is used to find the highest value of the variables in the study. The mean is used to measure the average of the research variables. Standard deviation is used to measure data that deviates from the mean (mean). The results of testing descriptive statistics are as follows.

\section{Capital Expenditures}

The minimum value of Capital Expenditures is Rp146,992,770,635, - by Wonosobo Regency and the maximum value is Rp1,789,394,044,827, - by the City of Surabaya. The standard deviation value of Capital Expenditures is Rp. 309,297,233,116.03, while the mean value is Rp. 498,931,589,914.62. Standard deviation value Capital expenditure tends to be lower when compared to the average value. Low standard deviations indicate that data points (data points) have a tendency to be very close to the average.

Locally-generated revenue

The minimum value of PAD is Rp. 66,385,348,153, - by Pangandaran Regency and the maximum value is Rp. $4,091,867,015,500$ - by the City of Surabaya. The standard deviation value of PAD is Rp.545,007,200,173.33, while the mean value is Rp. 462,319,882,062.31. PAD standard deviation values tend to be higher when compared to the average value.

\section{General Allocation Fund}

Minimum value found a correlation between independent variables (Ghozali, 2016). The multicollinearity test conducted for this study is using the value of Variance Inflation Factor (VIF). The model is declared free from the problem of multicollinearity if the VIF value is below 10 or the tolerance value is above 0.1 . 
Multicollinearity Test Results

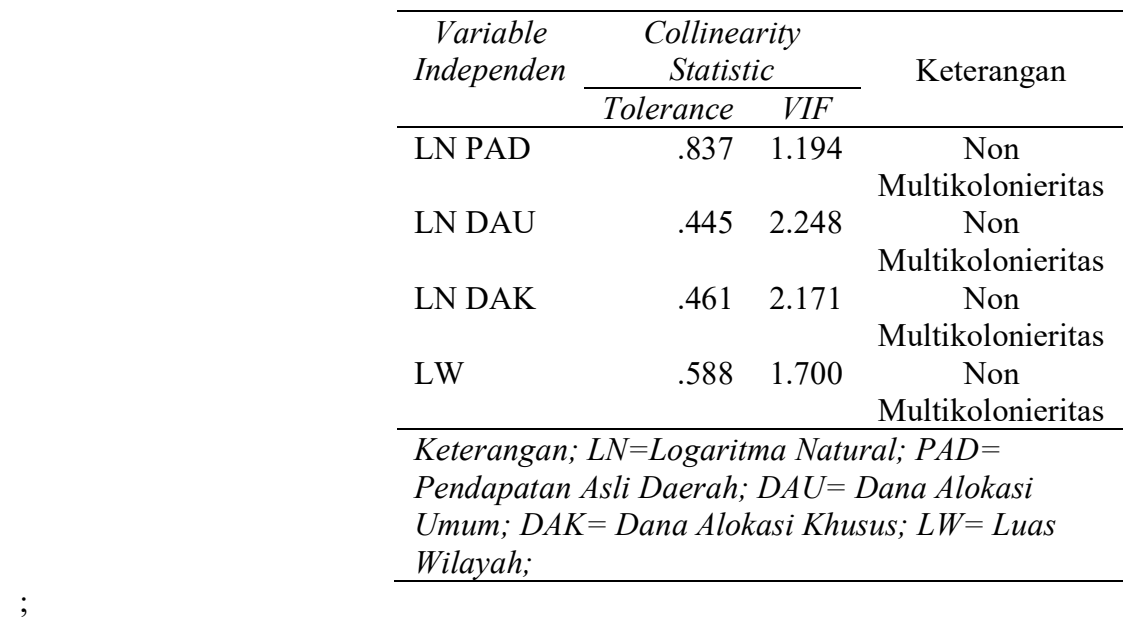

Result: SPSS data processing source

From the table above all VIF values are below 10, and tolerance values are above 0.1 . This means that this research model is free from multicollinearity.

\section{Heterocedasticity test}

In this study heteroscedasticity tests were carried out using the Glejser Test, where all independent variables were regressed with ABS residuals. If the asymp sig on each independent variable is above 0.05 , the data does not experience heteroscedasticity or means the data is declared homogeneous. Whereas vice versa if the asymp sig on each independent variable is below 0.05 then the data experiences heteroscedasticity.

\begin{tabular}{lcc}
\hline \multicolumn{1}{c}{ Model } & $\mathrm{t}$ & Sig. \\
\hline LN PAD & .679 & .499 \\
LN DAU & .330 & .742 \\
LN DAK & -.442 & .659 \\
LW & -.216 & .830 \\
\hline Keterangan; LN=Logaritma Natural; PAD= Pendapatan Asli Daerah; DAU= & Dana Alokasi Umum; DAK= Dana Alokasi Khusus; LW= Luas Wilayah; \\
\hline
\end{tabular}

Result: SPSS data processing source

Can be seen in the Tables in the sig column showing numbers above 0.05 for each variable. The PAD variable is 0.499 , the DAU variable is 0.742 , the DAK variable is 0.659 and the Area Area variable is 0.830 . Thus it is stated that each variable does not experience heteroscedasticity or each variable is homogeneous.

C. Hypothesis Test Results

\section{Determination Coefficient Test (R2)}

The results of testing the coefficient of determination in the Table shows the Adjusted R Square obtained at $61.1 \%$. This indicates that the capital expenditure allocation variable can be explained at $61.1 \%$ by its independent variables, namely PAD, DAU, DAK and Area Size. The rest of the remaining percentage is $38.9 \%$ influenced by other factors besides the above variables. 
Determination Coefficient Test Results (R2)

\begin{tabular}{ccccc}
\hline Model & $R$ & $R$ Square & $\begin{array}{c}\text { Adjusted } R \\
\text { Square }\end{array}$ & $\begin{array}{c}\text { Std. Error of the } \\
\text { Estimated }\end{array}$ \\
\hline 1 & $.791 \mathrm{a}$ & .626 & .611 & .33479 \\
\hline
\end{tabular}

Result: SPSS data processing source

\section{Simultaneous Significance Test (Test Statistic F)}

The results of the $\mathrm{F}$ statistical test in the Table show that the significance value is 0,000 . These results can be said to be significant because $0,000<0,05$ and has a calculated $F$ value of 42,178 . So it can be concluded that the variables PAD, DAU, DAK and Area of Area jointly influence the dependent variable, namely the allocation of Capital Expenditures. It also indicates that the regression model in this study is feasible for use in research.

\begin{tabular}{cccccc}
\hline Model & $\begin{array}{c}\text { Sum of } \\
\text { Squares }\end{array}$ & Df & $\begin{array}{c}\text { Mean } \\
\text { Square }\end{array}$ & $F$ & Sig. \\
\hline $\begin{array}{l}\text { Regressi } \\
\text { on } \quad 18.910\end{array}$ & 4 & 4.728 & 42.178 & $.000 \mathrm{~b}$ \\
$\quad$ Residual & 11.321 & 101 & .112 & \\
Total & 30.231 & 105 & & & \\
\hline
\end{tabular}

Result: SPSS data processing source

\section{Individual Parameter Significance Test (Test Statistic t)}

The $t$ statistical test aims to show the magnitude of the influence of one by one independent variables individually in explaining the dependent variable (Ghozali, 2016). The results of the $t$ statistical test from this study are as follows.

\begin{tabular}{llccl}
\hline & Model & $B$ & $t$ & Sig. \\
\hline 1 & Constant & 7.098 & 2.643 & .010 \\
& LN PAD & .476 & 9.401 & .000 \\
& LN DAU & .056 & .487 & .627 \\
& LN DAK & .206 & 2.087 & .039 \\
& LW & .000104 & 2.456 & .016 \\
\hline
\end{tabular}

Result: SPSS data processing source

Based on the above data, it can be seen that of the four independent variables included in the regression model only the DAU variable is not significant. The significance value of the variable is 0.627 or $>0.05$. While the other three variables, namely PAD, DAU, and Area Area are said to be significant because they have significant values below 0.05 .

$\operatorname{LnBM}=7,098+0,476 \mathrm{LnPAD}+0,056 \mathrm{LnDAU}+0,206 \mathrm{LnDAK}+0,000104 \mathrm{LW}$

D. Discussion of Research Results

1. Hypothesis 1

Variable Regional Original Income has a t count of 9,401 and a significance value of 0,000 . This means that Regional Original Income has a significant effect on Capital Expenditures. Regional Original Income has a positive sign of Capital Expenditures. This means that the greater the Regional Original Income will be the greater the 
Capital Expenditures as well as vice versa, the smaller the Regional Original Income will be the smaller the Capital Expenditures. Based on this explanation, Hypothesis 1: Regional Original Revenue has an effect on the allocation of Capital Expenditure received.

The results of this study s according to the results of the study of Nuarisa (2014), Kusnandar and Siswantoro (2012), Menes (2013) and Tuasikal (2008) which are several research references in this study. In the study of Kusnandar and Siswantoro (2012), Menes (2013) and Tuasikal (2008), it was also concluded that Regional Original Income had a positive and significant effect on the allocation of Capital Expenditures.

Regional Original Income statistically influences the allocation of Capital Expenditures can give an idea that Regional Original Income plays an important role in the development of the area. That is, by increasing Regional Original Income can increase flexibility to the area to allocate to activities or expenditures that can have an impact on regional development, especially infrastructure development. With the increase in regional development through the allocation of capital expenditure, it will have an impact on increasing the economic productivity of the region.

\section{Hypothesis 2}

The General Allocation Fund variable has a count of 0.487 and a significance value of 0.627 or $>0.05$ This means that the General Allocation Fund does not affect Capital Expenditures, then Hypothesis 2: General Allocation Funds have an effect on the allocation of Capital Expenditures rejected.

The results of this study are in accordance with the research of Kusnandar and Siswantoro (2012), Mentayani and Rusmanto (2013), Menes (2013) which became the reference for this study. In the study of Kusnandar and Siswantoro (2012), Mentayani and Rusmanto (2013), Menes (2013) also concluded that the General Allocation Fund had no effect on Capital Expenditures. The results of this study are different from the research conducted by Nuarisa (2014), Darmayasa and Suandi (2014), Tuasikal (2008), which concluded that the General Allocation Fund had an effect on the allocation of Capital Expenditures.

The General Allocation Fund statistically does not have an effect on Capital Expenditure, it can give an illustration that the General Allocation Fund does not participate in the increase in the level of Government Capital Expenditures. The basis for allocating the General Allocation Fund from the government is to add a Fiscal Gap with Basic Allocation. Where the Basic Allocation is the realization of the salaries of the previous year's employees. This means that the General Allocation Fund does not affect the Capital Expenditures, this may be due to the Regional Government Expenditures using the General Allocation Fund which is more used for Employee Expenditures and other government Operational Expenditures.

\section{Hypothesis 3}

The Special Allocation Fund variable has a t count of 2.087 and a significance value of 0.039 . This means that the Special Allocation Fund has a significant effect on Capital Expenditures. Special Allocation Funds have a positive sign of Capital Expenditures. This means that the greater the Special Allocation Fund the greater the Capital Expenditures as well as vice versa, the smaller the Special Allocation Fund, the smaller the Capital Expenditures will be. Based on this explanation, Hypothesis 3: Special Allocation Funds have an effect on the allocation of Capital Expenditure received.

The results of this study are in accordance with the results of the research of Nuarisa (2014), Wandira (2013) and Tuasikal (2008) which are the references of the research in this study. Research by Nuarisa (2014), Wandira (2013) and Tuasikal (2008) also concluded that the Special Allocation Fund had a positive and significant effect on the allocation of Capital Expenditures. Whereas in the Darmayasa and Suandi study (2014) it was concluded that the General Allocation Fund had no effect on Capital Expenditures.

Specific Allocation Funds statistically have an effect on the Capital Expenditure allocation which can provide an illustration that in addition to Regional Original Income, special Allocation Funds also participate in regional development. The Special Allocation Fund is a fund intended to fund special activities which are regional affairs and are a national priority, especially in efforts to fulfill the needs of community facilities and infrastructure. The utilization of the Special Allocation Fund is directed towards development investment activities, procurement, upgrading, repair of facilities, and physical infrastructure for public services with a long economic life. With the directed use of the Special Allocation Fund for these activities, the increase in government Capital Expenditures can be directly proportional to the increase in Special Allocation Funds provided by the government. 


\section{Hypothesis 4}

The area size variable has a t count of 2.456 and a significance value of 0.016 . This means that the area has a significant effect on capital expenditure. The area has a positive sign of capital expenditure. This means that the greater the area will be the greater the capital expenditure as well as vice versa, the smaller the area, the smaller the capital expenditure will be. Based on this explanation, Hypothesis 4: The area of influence on the allocation of Capital Expenditure is accepted.

The results of this study are in accordance with the results of the research of Kusnandar and Siswantoro (2012), which is one of the research references in this study Kusnandar and Siswantoro (2012) research also concluded that the area had a positive and significant effect on the allocation of capital expenditure. Whereas in the Menes study (2013) it was concluded that the Area did not affect Capital Expenditures. The area of an area statistically influential on the allocation of Capital Expenditures can give an idea that the greater the area of a region, the greater the Capital Expenditures incurred by the regional government. In accordance with Law No. 33 of 2004, one variable that reflects the need for the provision of facilities and infrastructure per unit area is the Area. The greater the scope of the area of a local government, the more facilities and infrastructure that must be provided by the regional government so as to increase the capital expenditure of the regional government so that good public services are available.

\section{CONCLUSION}

Based on testing and calculations that have been carried out and supported by theory and previous research, conclusions can be obtained as follows:

1. From the results of statistical tests that have been carried out, it can be concluded that Regional Original Income (PAD) has an effect on the allocation of capital expenditure with positive and significant results. This indicates that an increase in Regional Original Income is directly proportional to the increase in the allocation of Capital Expenditures.

2. From the results of statistical tests that have been carried out, it can be concluded that the General Allocation Fund (DAU) has a significance result above $>0.05$. This means that the General Allocation Fund does not affect the Capital Expenditures allocation.

3. From the results of statistical tests that have been conducted, it can be concluded that the Special Allocation Fund (DAK) has an effect on the allocation of capital expenditure with positive and significant results. Thus the higher the General Allocation Fund level, the greater the increase in the Capital Expenditures allocation.

4. From the results of statistical tests that have been done, it can be concluded that the Area variable influences the allocation of capital expenditure with positive and significant results. Thus the higher the level of the area of an area, the greater the increase in the allocation of capital expenditure.

\section{SUGGESTION}

not all financial reports or local government audit reports can be obtained easily, this is because access to data sources is very limited. Future research is expected to use variable data that is more varied, by adding other independent variables both size - size or types - types of other local government revenues, as well as non-financial variables such as population and economic growth.

The object of research is limited to districts / cities in Java, so the conclusions obtained have not been able to provide a comprehensive picture of the effect of independent variables on the allocation of regional capital expenditures in all regions of Indonesia. It is expected that further research will further broaden the scope of sample data from outside Java or even throughout Indonesia, so as to obtain maximum results.

\section{REFERNCES}

Arwati, D. dan Hadiati, N. 2013. Pengaruh Pertumbuhan Ekonomi, Pendapatan Asli Daerah dan Dana Alokasi Umum terhadap Pengalokasian Anggaran Belanja pada Pemerintah Daerah Kabupaten/Kota di Provinsi Jawa Barat. Seminar Nasional Teknologi Informasi dan Komunikasi Terapan 2013. Semarang.

Bastian, Indra. 2002. Sistem Akuntansi Sektor Publik. Jakarta: Salemba 4. 
Darmayasa, I. N., dan Suandi, I.K. 2014. Faktor Penentu Belanja Modal dalam APBD Pemerintah Provinsi. Simposium Nasional Akuntansi XVII. Mataram.

Ghozali, Imam. 2016. Aplikasi Analisis Multivariate Dengan Program SPSS. Edisi Keempat. Semarang: Badan Penerbit Universitas Diponegoro.

Halim, Abdul. 2004. Akuntansi Keuangan Daerah. Edisi Revisi. Jakarta: Salemba Empat.

Kharianto, D dan Adi, P. H. 2007. Hubungan Antara Dana Alokasi Umum, Belanja Modal, Pendapatan Asli Daerah dan Pendapatan Per Kapita. Simposium Nasional Akuntansi X. Makassar.

Kusnandar dan Siswantoro, D. 2012. Pengaruh Dana Alokasi Umum, Pendapatan Asli Daerah, Sisa Lebih Pembiayaan Anggaran, dan Luas Wilayah terhadap Belanja Modal. Simposium Nasional Akuntansi XV. Banjarmasin.

Mardiasmo. 2002. Otonomi dan Manajemen Keuangan Daerah. Yogyakarta: Penerbit Andi.

Menes, Ulva Navatilova. 2012. Pengaruh Dana Alokasi Umum, (DAU), Pendapatan Asli Daerah, Sisa Lebih Pembiayaan Anggaran (SiLPA), Luas Wilayah, dan jumlah Terhadap Alokasi Belanja Modal (Studi pada Kabupaten dan Kota Di Pulau Jawa). Skripsi. Universitas Sebelas Maret.

Mentayani, Ida dan Rusmanto. 2013. Pengaruh Pendapatan Asli Daerah, Dana Alokasi Umum dan Sisa Lebih Pembiayaan Anggaran terhadap Belanja Modal pada kota dan kabupaten di Pulau Kalimantan. Jurnal InFestasi. Vol. 9 (2), 91-102.

Nuarisa, S.A. 2013. Pengaruh PAD, DAU dan DAK Terhadap Pengalokasian Anggaran Belanja Modal. Accounting Analysis Jurnal. Universitas Negeri Semarang. Semarang.

Novianto, R. dan Hanafiah, R. 2015. Pengaruh Pendapatan Asli Daerah, Dana Perimbangan dan Kinerja Keuangan Terhadap Alokasi Belanja Modal pada Pemerintah Kabupaten/Kota di Provinsi Kalimantan Barat. Jurnal Ekonomi. Vol. 4 (1).

N Hidayah, H Setiyawati - Universitas

Tarumanagara Journal of Accounting, 2014Pengaruh Dana Alokasi Umum, Dana Alokasi Khusus Dan Pendapatan Asli Daerah Terhadap Belanja Langsung Di Propinsi Jawa Tengah

Oktora, F.E. dan W. Pontoh. 2013. Analisis Hubungan Pendapatan Asli Daerah, Dana Alokasi Umum, dan Dana Alokasi Khusus atas Belanja Modal (Pada Pemerintah Daerah Kabupaten Tolitoli Provinsi Sulawesi Tengah). Jurnal Accountability. Vol. 2 (1).

Jakarta.

. 2003. Undang-Undang Republik Indonesia No 17 tahun 2003 tentang Keuangan Negara,

. 2004. Undang-Undang Republik Indonesia No 32 tahun 2004 tentang Pemerintah Daerah,

Jakarta.

. 2004. Undang-Undang Republik Indonesia No 33 tahun 2004 tentang Perimbangan Keuangan antara Pemerintah Pusat dan Daerah, Jakarta.

. 2005. Peraturan Pemerintah Republik Indonesia No 55 tahun 2005 tentang Dana Perimbangan, Jakarta.

2006. Peraturan Menteri Dalam Negeri No 26 tahun 2006 tentang Pedoman Penyusunan Anggaran Pendapatan dan Belanja Daerah, Jakarta.

Jakarta.

. 2007. Undang-UndangRepublik Indonesia No 26 tahun 2007 tentang Penataan Ruang,

2008. Peraturan Dirjen Perbendaharaan No 33/PB/2008 tentang Pedoman Penggunaan Akun Pendapatan, Belanja Pegawai, Belanja Barang, dan Belanja Modal. Jakarta.

. 2010. Peraturan Pemerintah No 71 tahun 2010 tentang Standar Akuntansi Pemerintah,

Jakarta.

2013. Peraturan Menteri Dalam Negeri Republik Indonesia No. 64 Tahun 2013 Tentang

Penerapan Standar Akuntansi Pemerintahan Berbasis Akrual Pada Pemerintah Daerah. Jakarta. 


(a)

. 2014. Undang-Undang Republik Indonesia No 23 tahun 2014 tentang Pemerintah Daerah, Jakarta.

. 2015. Undang-Undang Republik Indonesia No 14 tahun 2015 tentang Anggaran Pendapatan Belanja Negara Tahun 2016, Jakarta.

2015. Peraturan Menteri Dalam Negeri Republik Indonesia No. 52 Tahun 2015 tentang Pedoman Penyusunan Anggaran Pendapatan dan Belanja Daerah Tahun 2016. Jakarta.

. 2015. Peraturan Menteri Keuangan Republik Indonesia No. 127/PMK.02/2015 tentang Klasifikasi Anggaran. Jakarta

2017. Peraturan Menteri Dalam Negeri Republik Indonesia No. 137 Tahun 2017 tentang Kode dan Data Wilayah Administrasi Pemerintahan. Jakarta.

Saragih, Juli Panglima. 2003. Desentralisasi Fiskal dan Keuangan Daerah dalam Otonomi. Ghalia Indonesia.

Sekaran, Uma dan Wiley. J. 2006. Metode Penelitian untuk Bisnis. Edisi Keempat. Jakarta: Salemba Empat.

Sudaryo, Yoyo. et al. 2017. Keuangan di Era Otonomi Daerah. Yogyakarta: Andi

Sularso, H., dan Restianto, Y. 2011. Pengaruh Kinerja Keuangan terhadap Alokasi Belanja Modal dan Pertumbuhan Ekonomi Kabupaten/Kota di Jawa Tengah. Media Riset Akuntansi, Vol. 1 (2).

Sumarmi, Saptaningsih. 2007. Pengaruh Pendapatan Asli Daerah, Dana Alokasi Umum, dan Dana Alokasi Khusus terhadap Alokasi Belanja Modal Daerah Kabupaten/Kota di Provinsi D.I. Yogyakarta. Tesis. Yogyakarta.

Tuasikal, Askam. 2008. Pengaruh DAU, DAK, PAD dan PDRB terhadap Belanja Modal Pemerintah Daerah Kabupaten/Kota di Indonesia. Jurnal Telaah \& Riset Akuntansi. Vol. 1 (2), 142-155.

Wandira, A.G. 2013. Pengaruh PAD, DAU, DAK, dan DBH terhadap Pengalokasian Belanja Modal. Accounting Analysis Journal. Vol. 2 (1). 